\title{
ANALISIS PERBANDINGAN ATAS MODEL REVALUASI ASET TETAP SESUAI PSAK NO. 16 (REVISI 2007) DAN DAMPAK PERPAJAKANNYA MENURUT UNDANG-UNDANG PAJAK
}

\author{
Chandra Pribadi \\ Dosen Tetap Fakultas Ekonomi Universitas Pakuan \\ Nurmiati \\ Mahasiswa Fakultas Ekonomi Universitas Pakuan
}

\begin{abstract}
ABSTRAK
Tujuan penelitian ini adalah untuk mengetahui bagaimana dampak revaluasi aset tetap terhadap perpajakan perusahaan. Penelitian ini dilakukan pada PDAM Tirta Jaya Mandiri Kabupaten Sukabumi. Metode analisis yang dilakukan dalam penelitian ini adalah deskriptif kualitatif non statistik (Descriptive non Statistic). Hasil penelitian bahwa revaluasi aset tetap memiliiki dampak terhadap pajak penghasilan final dimana dampak yang ditimbulkan dari kegiatan revaluasi aset tetap adalah adanya selisih lebih penilaian kembali aset tetap yang dikenakan pajak penghasilan final sebesar $10 \%$. Perusahaan dapat menghemat pajak sebesar 7\% (asumsi permohonan diajukan sejak 31 Oktober 2015 sampai dengan 31 Desember 2015 dan dikenakan tarif 3\%). Perusahaan dapat menghemat pajak sebesar 6\% (asumsi permohonan diajukan sejak 1 Januari 2016 sampai dengan tanggal 30 Juni 2016 dan dikenakan tarif 4\%) atau menghemat 4\% (asumsi permohonan diajukan sejak 1 Juli 2016 sampai dengan tanggal 31 Desember 2016 dan dikenakan tarif 6\%). Diskon tarif yang disediakan pemerintah pada tahun 2015 tidak pernah dimanfaatkan oleh perusahaan, padahal diskon tarif tersebut merupakan peluang bagi perusahaan untuk melakukan penilaian kembali (Revaluasi) aset tetap. Perusahaan sebaiknya mempertimbangkan untuk melakukan penilaian kembali (Revaluasi) atas aset tetapnya kembali dengan mempertimbangkan dampak positif bagi perusahaan yang ditimbulkan dari kegiatan tersebut.
\end{abstract}

Kata kunci: PSAK No.16, Revaluasi Aset Tetap, Dampak Revaluasi Aset Tetap.

\begin{abstract}
The purpose of this study was to determine how the impact of revaluation of fixed assets to corporate taxation. This research was conducted in PDAM Tirta Jaya Mandiri Sukabumi. The method of analysis in this research is descriptive qualitative non-statistical (non Descriptive Statistics). The results of the research that revaluation memiliiki impact on the final income tax where the impact of the activities of revaluation of fixed assets is the excess of the revaluation of fixed assets subject to final tax of $10 \%$. Companies can save on taxes by 7\% (assuming the petition filed since October 31, 2015 until December 31, 2015 and charged at 3\%). Companies can save on taxes by 6\% (assuming the petition filed since January 1, 2016 until the date of June 30, 2016 and charged at 4\%) or save 4\% (assuming the petition filed since July 1, 2016 until December 31, 2016 and charged at 6\%). Discount rate provided by the government in 2015 was never used by the company, whereas the discount rate is the opportunity for the company to undertake the revaluation (revaluation) of fixed assets. Companies should consider doing a reassessment (revaluation) on fixed assets in return taking into account the positive impact for the company arising from such activities.
\end{abstract}

Keywords: PSAK No.16, Revaluation of Fixed Assets, Fixed Asset Revaluation Impact.

\section{Pendahuluan}

Aset tetap merupakan salah satu dari beberapa akun perusahaan yang memiliki nilai yang cukup besar dan juga salah satu akun yang sangat penting bagi suatu entitas usaha. Sebagian perusahaan menginvestasikan sebagian besar modalnya dalam bentuk aset yang bersifat tahan lama yang digunakan untuk operasional perusahaan dalam 
mencapai tujuan yang telah ditetapkan. Hal inilah yang membuat para pemimpin perusahaan harus lebih berhati-hati ketika menerapkan kebijakan khususnya pada perlakuan akuntansi untuk aset tetap agar laporan keuangan perusahaan tetap mencerminkan posisi keuangan perusahaan yang wajar. Nilai aset tetap perusahaan akan mengalami peningkatan seiring dengan kondisi perekonomian di Indonesia. Meningkatnya harga-harga di pasaran menyebabkan nilai dari suatu aset tetap yang dimiliki oleh entitas usaha menjadi tidak wajar. Nilai sekarang suatu aset tetap yang diperoleh beberapa tahun lalu tidak sama dengan harga perolehan aset tersebut yang tercatat pada laporan posisi keuangan. Hal ini bisa terjadi karena akuntansi menganut prinsip harga perolehan (Historical Cost), di mana nilai suatu aset dicatat sebesar harga perolehannya (Hery 2013 ; 42). Faktor ini mendorong beberapa perusahaan untuk melakukan revaluasi pada aset tetapnya agar sesuai dengan nilai yang wajar.

Kewajaran penilaian aset tetap suatu perusahaan dapat disesuaikan dengan Pernyataan Standar Akuntansi Keuangan (PSAK) No.16 (Revisi 2007). Dalam Pernyataan Standar Akuntansi Keuangan (PSAK) No.16 (Revisi 2007) ini dinyatakan bahwa aset tetap adalah aset berwujud yang dimiliki untuk digunakan dalam produksi atau penyediaan barang atau jasa, untuk direntalkan kepada pihak lain, atau tujuan administratif dan diharapkan untuk digunakan selama lebih dari satu periode. Semua jenis aset tetap kecuali tanah akan semakin berkurang kemampuannya untuk memberikan jasa bersamaan dengan berlalunya waktu. Beberapa faktor yang mempengaruhi menurunnya kemampuan ini adalah pemakaian, keausan, ketidakseimbangan kapasitas yang tersedia dengan yang diminta dan keterbelakangan teknologi.
Berkurangnya kapasitas berarti berkurangnya nilai aset tetap yang bersangkutan. Hal ini perlu dicatat dan dilaporkan. Pengakuan adanya penurunan nilai aset tetap berwujud disebut penyusutan (Depreciation).

Berdasarkan Pernyataan Standar Akuntansi Keuangan (PSAK) No.16 (Revisi 2007) suatu aset tetap yang nilai wajarnya dapat diukur secara andal harus dicatat pada jumlah revaluasian, yaitu nilai wajar pada tanggal revaluasi dikurangi akumulasi penyusutan dan akumulasi rugi penurunan nilai yang terjadi setelah tanggal revaluasi. Revaluasi atas aset tetap harus dilakukan dengan keteraturan yang cukup reguler untuk memastikan bahwa jumlah tercatat tidak berbeda secara material dari jumlah yang ditentukan dengan menggunakan nilai wajar pada tanggal neraca.

Pernyataan Standar Akuntansi Keuangan (PSAK) No.16 (revisi 2007) mengakui adanya 2 (dua) model dalam pengukuran setelah pengakuan awal untuk aset tetap yaitu model biaya (Cost 3 Model) atau model revaluasi (Revaluation Model). Dari sisi perpajakan menyatakan bahwa perusahaan dapat menggunakan model revaluasi untuk tujuan perpajakan. Revaluasi aset tetap dapat dilakukan terhadap sebagian atau seluruh aset tetap berwujud yang terletak atau berada di Indonesia, dimiliki, dan dipergunakan untuk mendapatkan, menagih, dan memelihara penghasilan yang merupakan Objek Pajak.Revaluasi aset tetap dilakukan berdasarkan nilai pasar wajar yang ditentukan oleh jasa penilai atau ahli penilai, namun jika hasil dari jasa penilai belum dapat mencerminkan keadaan sebenarnya, maka nilai wajar akan ditentukan oleh Dirjen Pajak. Hal ini tentunya menambah daftar perbedaan perlakuan aset tetap antara Pernyataan Standar Akuntansi Keuangan (PSAK) No.16 (Revisi 2007) dengan peraturan 
perpajakan Indonesia. Perbedaan perlakuan tersebut mencakup perbedaan metode penyusutan, umur manfaat aset tetap dan kapan aset tetap disusutkan dan model revaluasi.

PDAM Tirta Jaya Mandiri Kabupaten Sukabumi merupakan perusahaan penyedia air minum untuk masyarakat di Kabupaten Sukabumi dan wilayah sekitarnya. Dalam kegiatan operasionalnya, PDAM Tirta Jaya Mandiri membutuhkan aset tetap untuk mendukung jalannya operasional perusahaan. Perusahaan harus melakukan pencatatan secara tepat atas semua aset yang dimilikinya.

Di dalam Laporan Keuangan PDAM Tirta Jaya Mandiri Kabupaten Sukabumi diuraikan bahwa perusahaan mengalami kerugian yang berulang kali dari tahun 1998 sampai dengan tahun 2004 dalam usahanya sehingga kerugian kumulatif termasuk tahun buku 2004 mencapai sejumlah Rp.8.140.717.763. Dalam tahun buku 2004 perusahaan telah melakukan revaluasi aset tetap tanah dan sebagian bangunan. Langkahlangkah yang telah diambil perusahaan tersebut mengakibatkan nilai aset yang disajikan dalam Neraca periode 31 Desember 2004 bertambah sebesar Rp.6.140.948.140 yang setelah dikompensasikan dengan rugi kumulatif sebesar Rp.8.140.717.763 masih terdapat saldo rugi kumulatif Rp.1.999.769.623. PDAM Tirta Jaya Mandiri Kabupaten Sukabumi terakhir melakukan revaluasi atas aset tetapnya pada tahun 2004 untuk jenis aset tetap tanah dan bangunan. Sampai dengan saat ini perusahaan belum lagi melakukan revaluasi kembali.

Sejak tahun 2005 sampai dengan saat ini PDAM Tirta Jaya Mandiri Kabupaten Sukabumi belum melakukanrevaluasi atas aset tetap lagi. Jika ditinjau dari sisi akuntansi, dimana Pernyataan Standar Akuntansi Keuangan (PSAK) No.16 (Revisi 2007) menjelaskan bahwa revaluasi atas aset tetap harus dilakukan dengan keteraturan yang cukup reguler yang dinilai menggunakan nilai wajar pada tanggal neraca.

Adapun tujuan dari penelitian dalam penelitian pada PDAM Tirta Jaya Mandiri Kabupaten Sukabumi adalah sebagai berikut: 1) Untuk mengetahui kecukupan atas keteraturan melakukan revaluasi aset tetap sesuai ketentuan PSAK No.16 (Revisi 2007) Pada PDAM Tirta Jaya Mandiri Kabupaten Sukabumi; 2) Untuk mengetahui apakah perusahaan perlu melakukan revaluasi atas aset tetap yang belum dilakukan revaluasi pada periode sebelumnya; dan 3) Untuk mengetahui bagaimana dampak revaluasi aset tetap terhadap perpajakan Pada PDAM Tirta Jaya Mandiri Kabupaten Sukabumi.

\section{Landasan Teori \\ 2.1. Revaluasi Aset Tetap}

Dalam Pernyataan Standar Akuntansi Keuangan No.16 (2007) setelah pengakuan sebagai aset, aset tetap yang nilai wajarnya dapat diukur secara andal dicatat pada jumlah revaluasian, yaitu nilai wajar pada tanggal revaluasi dikurangi akumulasi penyusutan dan akumulasi rugi penurunan nilai aset yang terjadi setelah tanggal revaluasi. Revaluasi harus dilakukan dengan keteraturan yang cukup reguler untuk memastikan bahwa jumlah tercatat tidak berbeda secara material dari jumlah yang ditentukan dengan menggunakan nilai wajar pada tanggal neraca.

Nilai wajar tanah dan bangunan biasanya ditentukan melalui penilaian yang dilakukan oleh penilai yang memiliki kualifikasi profesional berdasarkan bukti pasar. Nilai wajar pabrik dan peralatan biasanya menggunakan nilai pasar yang ditentukan oleh penilai. 
Jika tidak ada data pasar yang dapat dijadikan pasar penentuan nilai wajar karena sifat dari aset tetap yang khusus dan jarang diperjual-belikan, kecuali sebagai bagian dari bisnis yang berkelanjutan, entitas mungkin perlu mengestimasi nilai wajar menggunakan pendekatan penghasilan atau biaya pengganti yang telah disusutkan (Depreciated Replacement Cost Approach).

Frekuensi revaluasi tergantung perubahan nilai wajar dari suatu aset tetap yang direvaluasi. Jika nilai wajar dari aset yang direvaluasiberbeda secara material dari jumlah tercatatnya, maka revaluasi lanjutan perlu dilakukan. Beberapa aset tetap mengalami perubahan nilai wajar secara signifikan dan fluktuatif, sehingga perlu direvaluasi secara tahunan. Revaluasi tahunan seperti itu tidak perlu dilakukan apabila perubahan nilai wajar tidak signifikan. Namun demikian, aset tersebut mungkin perlu direvaluasi setiap tiga atau lima tahun sekali.

Apabila suatu aset tetap direvaluasi, akumulasi penyusutan pada tanggal revaluasi diperlakukan dengan salah satu cara berikut ini :

1. Disajikan kembali secara proposional dengan perubahan dalam jumlah tercatat bruto dari aset sehingga jumlah tercatat aset setelah revaluasi sama dengan jumlah revaluasian. Metode ini sering digunakan apabila aset direvaluasi dengan cara memberi indeks untuk menentukan biaya pengganti yang telah disusutkan.

2. Dieliminasi terhadap jumlah tercatat bruto dari aset dan jumlah tercatat neto setelah eliminasi disajikan kembali sebesar jumlah revaluasian dari aset tersebut. Metode ini sering digunakan untuk bangunan.
Jumlah penyesuaian yang timbul dari penyajian kembali atau eliminasi akumulasi penyusutan membentuk bagian dari kenaikan atau penurunan dalam jumlah tercatat yang ditentukan. Jika suatu aset direvaluasi, maka seluruh aset tetap dalam kelompok yang sama harus direvaluasi. Suatu kelompok aset tetap adalah pengelompokkan aset yang memiliki sifat dan kegunaan yang serupa dalam operasi normal entitas.

Aset-aset dalam suatu kelompok aset tetap harus direvaluasi secara bersamaan untuk menghindari revaluasi secara selektif dan bercampurnya biaya perolehan dan nilai lainnya pada saat yang berbeda-beda. Namun, suatu kelompok aset dapat direvaluasi secara bergantian (Rolling basis) sepanjang revaluasi dari kelompok aset tersebut dapat diselesaikan secara lengkap dalam waktu yang singkat dan sepanjang revaluasi dimutakhirkan.

Jika jumlah tercatat aset meningkat akibat revaluasi, kenaikan tersebut langsung dikredit ke ekuitas pada bagian surplus revaluasi. Namun, kenaikan tersebut harus diakui dalam laporan laba rugi hingga sebesar penurunan nilai aset akibat revaluasi yang pernah diakui sebelumnya dalam laporan laba rugi.

Jika jumlah tercatat aset turun akibat revaluasi, penurunan tersebut diakui dalam laporan laba rugi. Namun, penurunan nilai akibat revaluasi tersebut langsung didebit ke ekuitas pada bagian surplus revaluasi selama penurunan tersebut tidak melibihi saldo kredit surplus revaluasi untuk aset tersebut.

Surplus revaluasi aset tetap yang telah disajikan dalam ekuitas dapat dipindahkan langsung ke saldo laba pada saat aset tersebut dihentikan pengakuannya. Hal ini meliputi pemindahan sekaligus surplus revaluasi pada saat penghentian atau pelepasan aset tersebut. Namun, sebagian surplus revaluasi tersebut dapat dipindahkan 
sejalan dengan penggunaan aset oleh entitas. Dalam hal ini, surplus revaluasi yang dipindahkan ke saldo laba adalah sebesar perbedaan antara jumlah penyusutan berdasarkan nilai revaluasian aset dengan jumlah penyusutan berdasarkan biaya perolehan aset tersebut. Pemindahan surplus revaluasi ke saldo laba tidak dilakukan melalui laporan laba rugi.

\section{Hal-Hal yang Perlu Diperhatikan Dalam Melakukan Revaluasi}

Erly Suandy (2013, 45) menjelaskan mengenai jenis revaluasi aset tetap. Terdapat 2 (dua) jenis revaluasi aset tetap yaitu revaluasi parsial dan revaluasi menyeluruh. Revaluasi parsial berarti perusahaan hanya melakukan revaluasi atas sebagaian aset tetap yang ada sesuai pertimbangan perusahaan. Objek revaluasi adalah aset berwujud dalam bentuk tanah, kelompok bangunan, dan bukan bangunan yang tidak dimaksudkan untuk dialihkan atau dijual atau bukan barang dagangan.

\subsection{Aspek Perpajakan Pada Aset Tetap}

Pembayaran Pajak Penghasilan Sebesar Sepuluh Persen yang Bersifat Final

Erly Suandy (2013; 45) menjelaskan pertimbangan tarif pajak penghasilan sebesar 10\% (sepuluh persen). Bagi perusahaan yang akan melakukan revaluasi aset atas tetapnya perlu melakukan pertimbangan apakah membayar pajak penghasilan sebesar $10 \%$ (sepuluh persen) akan lebih menguntungkan dibandingkan dengan tarif pajak penghasilan $30 \%$ (sepuluh persen) yang merupakan tarif pajak penghasilan tertinggi. Aset tetap yang sudah direvaluasi akan disusutkan berdasarkan nilai revaluasi. Biaya penyusutan akan mengurangi
Penghasilan Kena Pajak. Jangka waktu penyusutan aset tetap dilakukan sesuai dengan kelompok aset tetap yang bersangkutan, walalupun aset yang direvaluasi tadinya sudah digunakan lebih dari separuh umur. Selisih akibat revaluasi aset tetap setelah dikompensasikan dengan kerugian fiskal dan atau sisa kerugian fiskal pada tahuntahun yang lalu (Pasal 6 ayat $2 \mathrm{UU} \mathrm{PPh}$ ) dikenakan $\mathrm{PPh}$ Final sebesar 10\% (sepuluh persen).

\section{Persyaratan Administrasi Setelah Revaluasi Aset Tetap}

Erly Suandy (2013; 43) setelah melakukan revaluasi aset tetap maka Wajib Pajak memberitahukan hasil penilaian dengan mengisi formulir yang telah disediakan kepada Dirjen Pajak, tempat Wajib Pajak terdaftar dengan melampirkan hal-hal sebagai berikut:

1. Laporan penilaian dari perusahaan penilai atau penilai profesional yang diakui oleh pemerintah.

2. Neraca penyesuaian yang telah diaudit oleh akuntan publik secara jelas terlihat nilai aset sebelum dan sesudah dilakukannya revaluasi aset tetap.

3. Perhitungan selisih akibat revaluasi aset tetap dan perhitungan besarnya Pajak Penghasilan terutang.

4. Surat Setoran Pajak (SSP)

\section{Penyusutan dan Amortisasi}

Perolehan harta berwujud dan hak atau biaya lain, misal pengeluaran yang menurut sifatnya merupakan pembayaran di muka seperti sewa untuk beberapa tahun yang dibayarkan sekaligus yang memiliki masa manfaat lebih dari 1 (satu) tahun tidak boleh dibiayakan sekaligus melainkan melalui penyusutan atau amortisasi sebagaimana dimaksud dalam Pasal 11 dan Pasal 11A UU PPh. Penyusutan atas pengeluaran 
untuk memperoleh harta berwujud dan amortisasi atas pengeluaran untuk memperoleh hak dan atas biaya lain yang mempunyai masa manfaat lebih dari 1 (satu) tahun dapat dibiayakan. Menurut Pasal 6 Ayat 1 huruf $b$, penyusutan (depresiasi) dan amortisasi merupakan biaya untuk mendapatkan, menagih, dan memelihara penghasilan sehingga dapat dikurangkan dari penghasilan bruto. Penyusutan adalah pengalokasian harga perolehan untuk harta tetap berwujud, sedangkan amortisasi merupakan konsep alokasi harga perolehan untuk harta tetap tidak berwujud dan hak pengelolaan sumber daya alam (deplesi).

Penyusutan diterapkan atas pengeluaran untuk pembelian, pendirian, penambahan, perbaikan, atau perubahan harta berwujud, kecuali tanah yang berstatus hak milik, hak guna bangunan, hak guna usaha, dan hak pakai, yang dimiliki dan digunakan untuk mendapatkan, menagih, dan memelihara penghasilan yang mempunyai masa manfaat lebih dari 1 (satu) tahun dengan cara mengalokasikan pengeluaran tersebut selama masa manfaat harta tersebut melalui metode penyusutan.

Dalam pengaturan tersebut, persyaratan aset yang dapat disusutkan menurut ketentuan perpajakan meliputi :

1. Harta yang dapat disusutkan adalah harta berwujud

2. Harta tersebut mempunyai masa manfaat lebih dari 1 (satu) tahun

3. Harta tersebut digunakan untuk mendapatkan, menagih, dan memelihara penghasilan

Jumlah yang dapat disusutkan dari suatu aset dialokasikan secara sistematis sepanjang umur manfaatnya. Jumlah yang dapat disusutkan dari suatu aset tetap adalah jumlah tercatatnya (baik mengikuti model biaya maupun model revaluasi) dikurangi dengan nilai residu aset yang bersangkutan.
Manfaat ekonomis masa depan melekat pada aset yang dikonsumsi oleh entitas, terutama melalui penggunaan aset itu sendiri. Namun, beberapa faktor lain seperti keusangan teknis, keusangan komersil, dan keausan selama aset tersebut tidak terpakai, sering mengakibatkan menurunnya manfaat ekonomis yang dapat diperoleh dari aset tersebut. Berkaitan dengan hal tersebut, seluruh faktor berikut ini diperhitungkan dalam menentukan umur manfaat dari setiap aset :

1. Prakiraan daya pakai sari aset yang bersangkutan. Daya pakai atau daya guna tersebut dinilai dengan merujuk pada prakiraan kapasitas atau kemampuan fisik aset tersebut untuk menghasilkan sesuatu;

2. Prakiraan tingkat keausan fisik, yang tergantung pada faktor pengoperasian aset tersebut, seperti jumlah penggiliran penggunaan aset dan program pemeliharaan aset dan perawatannya serta perawatan dan pemeliharaan aset pada saat aset tersebut tidak digunakan;

3. Keusangan teknis dan keusangan komersil yang diakibatkan oleh perubahan atau peningkatan produksi, atau karena perubahan permintaan pasar atas produk atau jasa yang dihasilkan oleh aset tersebut; dan

4. Pembatasan penggunaan aset karena aspek hukum atau peraturan tertentu seperti berakhirnya waktu penggunaan sehubungan dengan sewa.

Umur manfaat aset tetap ditentukan berdasarkan kegunaan yang diharapkan oleh entitas. Estimasi umur manfaat suatu aset merupakan hal yang membutuhkan pertimbangan berdasarkan pengalaman entitas terhadap aset yang serupa. 


\section{Metode Penyusutan Atas Aset Tetap Menurut Perpajakan}

Wirawan dan Diaz Priantara (2015; 230) menjelaskan metode penyusutan menurut Ketentuan Perundang-undangan Perpajakan sebagaimana telah diatur dalam Pasal 11A Undang-Undang No.36 Tahun 2008 tentang Pajak Penghasilan.

1. Metode garis lurus (Straight Line Method), yaitu metode dengan bagian-bagian yang sama besar selama masa manfaat yang ditetapkan untuk harta tersebut.

2. Metode saldo menurun (Declining Balance Method), yaitu metode dengan bagian-bagian yang menurun dengan cara menetapkan tarif penyusutan atas nilai sisa buku, dan pada akhir masa manfaat nilai sisa buku disusutkan sekaligus.

\section{Metodologi Penelitian}

Dalam penelitian ini, penulis menggunakan jenis penelitian deskriptif yang bersifat kualitatif non statistik. Penelitian ini menguraikan secara deskriptif dengan mengumpulkan fakta dan identifikasi data yang membahas revaluasi aset tetap dan dampak perpajakannya menurut undang-undang pajak pada lokasi penelitian PDAM Tirta Jaya Mandiri Kabupaten Sukabumi.

Metode pengumpulan data yang dilakukan oleh penulis dalam penelitian ini adalah dengan menggunakan metode pengumpulan data primer melalui observasi dan wawancara yang dilakukan di PDAM Tirta Jaya Mandiri Kabupaten Sukabumi.

Metode analisis yang dilakukan dalam penelitian ini adalah deskriptif kualitatif non statistik (Descriptive non Statistic). Tujuan penelitian ini adalah untuk menggambarkan revaluasi atas aset tetap yang menjadi perhatian khusus dan memberikan perlakuan khusus terhadap revaluasi aset tetap tersebut. Secara teknis proses analisis data sebagai berikut :

1. Mengumpulkan data yang berkaitan dengan aset tetap perusahaan.

2. Melihat besaran kenaikan nilai aset tetap setelah melakukan penilaian kembali (revaluasi) aset tetap.

3. Melihat besaran kerugian fiskal yang dapat dikompensasikan dengan selisih lebih akibat revaluasi (jika ada).

4. Menghitung besaran pajak terutang yang harus dibayarkan oleh perusahaan sebagai dampak perpajakan atas penilaian kembali (revaluasi) aset tetap.

5. Membandingan pelaksanaan revaluasi aset tetap menurut Pernyataan Standar Akuntansi Keungan (PSAK) No. 16 (Revisi 2007) dan Menurut Aturan Perpajakan.

6. Melihat dampak revaluasi aset tetap.

\section{Hasil dan Pembahasan}

4.1. Pelaksanaan Penilaian (Revaluasi) Aset Tetap Pada PDAM Tirta Jaya Mandiri Kabupaten Sukabumi

\subsubsection{Kebijakan Aset Tetap}

Aset tetap PDAM Tirta Jaya Mandiri Kabupaten Sukabumi adalah aset berwujud yang dimiliki untuk digunakan dalam produksi dan distribusi air atau penyediaan barang atau jasa, untuk disewakan ke pihak lain, atau untuk tujuan administratif, dan diharapkan akan digunakan lebih dari satu periode. Pada saat pengakuan awal aset tetap diukur sebesar biaya perolehan yang meliputi :

1. Harga beli termasuk biaya hukum dan broker, bea impor dan pajak pembelian yang tidak boleh dikreditkan. 
2. Biaya yang dapat diatribusikan langsung untuk membawa aset ke lokasi dan kondisi yang diinginkan agar aset tetap siap digunakan sesuai dengan maksud manajemen.

Aset tetap yang dibangun sendiri dicatat sebesar seluruh nilai bahan peralatan yang digunakan, biaya pengerjaan saat biaya-biaya lainnya yang terkait dengan pembangunan aset tetap tersebut. Khusus tanah dan bangunan dicatat secara terpisah meskipun diperoleh secara bersamaan. Pengeluaran harus ditambahkan pada jumlah tercatat aset tetap hanya jika memperpanjang umur manfaat atau yang kemungkinan besar memberi manfaat ekonomi di masa yang akan datang dalam bentuk peningkatan kapasitas, mutu produksi, atau peningkatan standar kinerja.

Beban penyusutan diakui dalam laporan laba rugi dan dialokasikan selama umur manfaat aset tetap. Penyusutan dimulai pada saat aset tetap tersedia untuk digunakan, dan dihentikan pada saat aset tetap dihentikan pengakuannya. Penyusutan tidak dihentikan ketika aset tetap tidak digunakan atau dihentikan penggunaan aktifnya, kecuali aset tetap tersebut telah disusutkan secara penuh. Metode penyusutan, penentuan masa manfaat ekonomi, dan tarif penyusutan aset tetap PDAM Tirta Jaya Mandiri Kabupaten Sukabumi mengacu pada peraturan perpajakan yang berlaku pada periode yang bersangkutan.

Jika terdapat indikasi penurunan nilai aset tetap, maka akan dilakukan estimasi nilai wajar dikurangi dengan biaya untuk menjual aset tersebut, dan selisih dengan nilai tercatat aset tetap diakui sebagai kerugian penurunan nilai aset tetap.

Penilaian kembali atau revaluasi aset tetap dilakukan hanya jika terdapat ketentuan pemerintah yang mengharuskan hal tersebut dilaksanakan.
Pelaksanaan dan dampak penilaian kembali aset tetap akan diungkapkan dalam laporan keuangan, dan selisih antara nilai revaluasi dengan nilai tercatat aset tetap diakui dalam ekuitas dengan nama "Surplus Revaluasi Aset Tetap".

\subsubsection{Nilai Perolehan Aset Tetap}

Suatu aset tetap yang memenuhi kualifikasi untuk diakui sebagai aset pada awalnya harus diukur sebesar biaya perolehan. Harga perolehan aset tetap meliputi jumlah uang yang dikeluarkan untuk memperoleh aset tetap tersebut ditambahkan dengan biaya-biaya yang dapat diatribusikan secara langsung untuk membawa aset tetap ke lokasi sampai aset tetap siap digunakan sesuai dengan maksud manajemen.

Masing-masing jenis aset tetap memiliki komponen biaya perolehan yang berbeda dengan jenis aset tetap yang lainnya. Sebagai contoh komponen biaya perolehan untuk jenis aset tetap tanah berbeda dengan komponen biaya perolehan untuk jenis aset tetap bangunan. Komponen biaya perolehan adalah biaya yang dapat diatribusikan secara langsung ke dalam aset tetap, tetapi ada juga yang bukan merupakan komponen biaya perolehan sehingga biaya tersebut tidak dapat diatribusikan ke dalam aset tetap. Dalam penelitian ini penulis mengelompokan biaya berdasarkan wujudnya menjadi biaya fisik dan biaya non fisik yang telah dikapitalisasi oleh PDAM Tirta Jaya Mandiri Kabupaten Sukabumi ke dalam aset tetapnya. Biaya fisik yang dimaksudkan adalah biaya-biaya yang yang terdapat komponen bahan material di dalamnya, dan biaya non fisik yang dimaksudkan adalah biaya biaya-biaya yang sifatnya pekerjaan dan tidak memerlukan kompnen bahan material di dalamnya. 
Dari ...... dapat diketahui total biaya fisik dan biaya non fisik masingmasing sebesar Rp.1.788.545.903 dan Rp.642.059.846. Dari jumlah tersebut dapat diketahui perbedaan biaya fisik dan non fisik sebesar Rp.1.146.486.057. Terdapat kesalahan pencatatan pihak manajemen perusahaan dalam aset tetap instalasi perpompaan yaitu pembayaran hutang sebesar Rp.98.175.000 yang dikapitalisasi ke dalam akun aset tetap perusahaan. Pembayaran hutang ini sebenarnya adalah pembelian aset tetap perusahaan yang salah dicatat oleh pihak manajemen perusahaan.Jika pembayaran hutang tersebut dikeluarkan dari komponen biaya-biaya maka jumlah biaya non fisik pada instalasi perpompaan menjadi 0 (nol) dan total biaya non fisik secara keseluruhan menjadi sebesar Rp.543.884.846. Perbedaan biaya fisik dan non fisik menjadi sebesar Rp.1.244.661.057.

Pada dasarnya, biaya-biaya yang dikeluarkan atas aset tetap dapat diklasifikasi menjadi empat tahap, yaitu tahap pendahuluan, sebelum perolehan, perolehan atau konstruksi, dan pemakaian. Dalam empat tahap tersebut terdapat biaya-biaya yang dapat dikapitalisasi ke dalam aset tetap dan ada juga biaya-biaya yang tidak dapat dikapitalisasi ke dalam aset tetap. Kapitalisasi merupakan pengeluaran yang diakui sebagai penambah nilai aset di Neraca yang terjadi pada saat perolehan awal aset dan setelah perolehan awal aset.

Tahap pendahuluan terjadi sebelum pihak perusahaan yakin atas kemungkinan dilakukannya pembelian aset tetap. Selama tahap ini, perusahaan biasanya akan melakukan studi kelayakan dan analisis keuangan untuk menentukan kemungkinan diperolehnya aset tetap. Biaya-biaya yang dikeluarkan dalam tahap pendahuluan ini tidaklah dapat dikaitkan dengan aset tetap tertentu, sehingga harus diperlakukan sebagai pengeluaran pendapatan.

Pada tahap pra perolehan, keputusan untuk membeli aset tetap telah menjadi mungkin, namun belum terjadi. Biaya-biaya yang dikeluarkan dalam tahap ini, seperti biaya survei, sudah dapat dikaitkan dengan aset tetap tertentu yang akan dibeli sehingga harus diperlakukan sebagai pengeluaran modal.

Dalam tahap perolehan atau konstruksi, pembelian aset tetap terjadi atau konstruksi telah dimulai, namun aset tetap tersebut belum siap untuk digunakan. Biaya-biaya yang terkait langsung dengan aset tetap yang dibeli ini harus dikapitalisasi dalam akun aset tetap tersebut. Contohnya adalah harga beli mesin, pajak, ongkos angkut, biaya asuransi selama dalam perjalanan, ongkos pemasangan dan biaya uji coba sampai mesin tersebut benar-benar dapat dioperasikan akan dicatat dalam akun mesin. Demikian juga, untuk bangunan yang dibangun sendiri, biaya-biaya yang terkait langsung dengan pembangunan gedung baru tersebut akan dikapitalisasi sebagai akun pekerjaan dalam penyelesaian. Ketika bangunan tersebut telah selesai dibangun dan siap untuk dimanfaatkan, maka biaya yang telah dikapitalisasi sebagai akun pekerjaan dalam penyelesaian akan ditransfer ke dalam akun aset tetap terkait, yaitu akun bangunan. Contohnya adalah biaya arsitek, biaya untuk membeli bahanbahan bangunan, biaya upah pekerja, biaya sewa peralatan untuk membangun, bahkan termasuk bunga atas dana yang dipinjam untuk membiayai pembangunan gedung baru tersebut.

Dalam tahap pemakaian, aset tetap telah siap digunakan. Sepanjang tahap ini, aset tetap seharusnya disusutkan. Selama tahap ini, segala aktivitas perbaikan dan pemeliharaan atas aset tetap yang sifatnya normal serta 
berulang harus dicatat langsung ke dalam akun beban untuk periode bersangkutan. Sedangkan biaya yang terjadi untuk memperoleh tambahan komponen aset tetap atau mengganti komponen yang sudah ada haruslah dikapitalisasi, sepanjang biaya-biaya ini dapat meningkatkan efisiensi operasional dan kapasitas produktif aset tetap atau memperpanjang masa manfaat aset tetap bersangkutan.

Perlakuan akuntansi terhadap pengeluaran-pengeluaran yang berhubungan dengan perolehan dan penggunaan aset tetap dapat dibagi menjadi dua, yaitu:

1. Pengeluaran modal

Merupakan pengeluaranpengeluaran untuk memperoleh suatu manfaat yang akan dirasakan lebih dari satu periode akuntansi dan akan dicatat dalam rekening aset (dikapitalisasi).

2. Pengeluaran pendapatan

Merupakan pengeluaranpengeluaran untuk memperoleh suatu manfaat yang hanya dirasakan dalam periode akuntansi yang bersangkutan dan dicatat dalam rekening biaya.

Dalam praktiknya di PDAM Tirta Jaya Mandiri Kabupaten Sukabumi pengeluaran yang terkait dengan aset tetap perusahaan dicatat sebagai pengeluaran barang modal dan dikapitalisasikan ke dalan akun aset tetap perusahaan apabila mempunyai nilai minimal sebesar Rp.1.000.000, dan tidak dimaksudkan untuk dijual kembali. Tetapi ada beberapa pengeluaran yang nominalnya dibawah Rp.1.000.000 tetapi oleh manajemen pengeluaran tersebut dikapitaliasasi ke dalam aset tetap hanya jika memperpanjang umur manfaat atau yang kemungkinan besar memberi manfaat ekonomi di masa yang akan datang dalam bentuk peningkatan kapasitas, mutu produksi, atau peningkatan standar kinerja.Contohnya seperti accessories. Pengeluaran tersebut akan menambahkan harga perolehan atau masa manfaat dari aset tersebut. Pengeluaran seperti ini terjadi apabila aset tetap diperbaharui dengan melakukan penambahan komponen tertentu yang dapat meningkatkan nilai tercatat dan memperpanjang masa manfaat aset tersebut.

Perusahaan mengkapitalisasi semua biaya yang dikeluarkan oleh perusahaan ke dalam akun aset tetap perusahaan, meskipun ada beberapa biaya yang seharusnya tidak boleh dikapitalisasi ke dalam akun aset tetap perusahaan, namun oleh manajemen perusahaan, biaya-biaya tersebut dikapitalisasi ke dalam akun aset tetap perusahaan. Biaya-biaya tersebut adalah biaya perbaikan jembatan pipa sebesar Rp.49.531.400, biaya pembenahan jalur sebesar Rp.6.905.000, biaya pengelasan sebesar Rp.3.500.000, biaya normalisasi sebesar Rp.9.390.000, biaya penggantian pipa sebesar Rp.6.020.000, dan biaya perbaikan kebocoran pipa sebesar Rp.431.000. Biaya-biaya tersebut sifatnya normal dikeluarkan oleh perusahaan serta dilakukannya secara berulang.Menurut PSAK No.16, perusahaan seharusnya mencatat pengeluaran tersebut sebagai pengeluran beban, karena pengeluaran tersebut termasuk ke dalam salah satu pengeluaran rutin yang sering dilakukan dalam rangka memelihara aset tetap untuk dapat beroperasi sebagaimana mestinya.

Ada juga biaya perencanaan sebesar Rp.62.657.200 tidak dapat dikapitalisasi namun oleh manajemen perusahaan dikapitalisasi ke dalan akun aset tetap perusahaan. Biaya perencanaan ini termasuk ke dalam tahap pendahuluan. Biaya-biaya yang dikeluarkan dalam tahap pendahuluan ini tidaklah dapat dikaitkan dengan aset 
tetap tertentu, sehingga harus diperlakukan sebagai pengeluaran pendapatan dan dicatat sebagai rekening biaya.

\subsubsection{Penilaian Kembali (Revaluasi) Aset Tetap}

Berdasarkan laporan auditor, diketahui bahwa perusahaan mengalami kerugian yang berulang kali dari tahun 1998 sampai dengan tahun 2004 dalam usahanya sehingga kerugian kumulatif termasuk tahun buku 2004 mencapai Rp8.140.717.763,00. Untuk menanggulangi hal tersebut, perusahaan melakukan upaya-upaya untuk menyehatkan keuangan perusahaan salah satunya dengan melaksanakan penilaian kembali (revaluasi) aset tetap yang dilakukan oleh PT. Tetra Hedra Ekatama (Appraisal and Property Consultant). Penilaian kembali (Revaluasi) aset tetap dilakukan sesuai dengan Surat Perintah Kerja Direktur Utama PDAM Kabupaten Sukabumidengan Nomor 104/SPK/THE/VII/2004 tanggal 21 Juni 2004. Hasil penilaian kembali (Revaluasi) yang dilakukan oleh PT. Tetra Hedra Ekatama (Appraisal and Property Consultant) disajikan pada tabel 1.

\section{Tabel 1 \\ PDAM Tirta Jaya Mandiri Kabupaten Sukabumi Daftar Nilai Aset Tetap Sebelum dan Sesudah Revaluasi Tahun 2004}

\begin{tabular}{|c|l|r|r|}
\hline No & \multicolumn{1}{|c|}{ Jenis Aset Tetap } & $\begin{array}{c}\text { Sebelum } \\
\text { Revaluasi }\end{array}$ & $\begin{array}{c}\text { (Dalam Rupiah) } \\
\text { Sesudah } \\
\text { Revaluasi }\end{array}$ \\
\hline 1 & Tanah dan Penyempurnaannya & 482.424 .260 & 5.980 .411 .000 \\
\hline 4 & Instalasi Pengolahan Air & 214.369 .805 & 355.131 .305 \\
\hline 6 & Gedung dan Bangunan & 528.071 .675 & 1.030 .271 .575 \\
\hline & Jumlah & 1.224 .865 .740 & 7.365 .813 .880 \\
\hline
\end{tabular}

Sumber data : Laporan Keuangan PDAM Tirta Jaya Mandiri Kabupaten Sukabumi Tahun 2004

Dari tabel 1 menunjukan besaran nilai aset tetap perusahaan sebelum dan sesudah perusahaan melakukan penilaian kembali (Revaluasi) aset tetap tahun 2004. Langkah-langkah yang diambil perusahaan tersebut mengakibatkan adanya selisih lebih penilaian kembali (Revaluasi) aset tetap sebesar Rp.6.140.948.140 hasil ini di dapat dari (Rp.7.365.813.880 - Rp.1.224.865.740) dengan kondisi tersebut aset tetap perusahaan mengalami peningkatan nilai yang cukup besar. Dapat diketahui bahwa nilai aset tetap dari tanah dan penyempurnaannya mengalami peningkatan yang cukup signifikan dari Rp.482.424.260 menjadi Rp.5.980.411.000. Sedangkan nilai aset tetap dari instalasi pengolahan air mengalami peningkatan dari Rp.214.369.805 menjadi Rp.355.131.305 dan peningkatan yang cukup signifikan juga terjadi pada nilai aset tetap dari gedung dan bangunan dimana nilai aset tetap sebelum penilaian kembali (Revaluasi) sebesar Rp.528.071.675 menjadi Rp.1.030.271.575. Penilaian kembali (Revaluasi) sesuai dengan Keputusan Menteri Keuangan Republik Indonesia Nomor 486/KMK.03/2002 tanggal 28 November 2002.

Dari hasil penilaian kembali (Revaluasi) aset tetap yang dilakukan PDAM Tirta Jaya Mandiri Kabupaten Sukabumi menghasilkan selisih lebih penilaian kembali aset tetap yang dikompensasikan terhadap kerugian kumulatif perusahaan. Perhitungan 
kompensasi kerugian terhadap selisih lebih penilaian kembali aset tetap disajikan pada tabel 2.

Tabel 2

PDAM Tirta Jaya Mandiri Kabupaten Sukabumi Perhitungan Kompensasi Kerugian Terhadap Selisih Lebih Penilaian Kembali Aset Tetap Sampai Dengan Tahun 2004

\begin{tabular}{|l|r|r|}
\hline \multicolumn{1}{|c|}{ Tahun } & \multicolumn{1}{c|}{ Rugi Komersial } & \multicolumn{1}{c|}{ Rugi Fiskal } \\
\hline 1998 sampai dengan 2003 & $6.918 .716 .565,85$ & $5.148 .027 .845,79$ \\
\hline 2004 & $1.215 .199 .197,00$ & $924.095 .402,00$ \\
\hline Sampai dengan 2004 & $8.133 .835 .765,85$ & $6.072 .123 .247,79$ \\
\hline Perhitungan : & $6.140 .948 .140,00$ & $6.140 .948 .140,00$ \\
\hline Selisih Lebih Revaluasi & $(1.992 .887 .622,85)$ & $68.824 .892,22$ \\
\hline Rugi Komersial & & $6.882 .489,22$ \\
\hline Selisih Lebih / Laba Fiskal & & \\
\hline PPh 10\% (Final) & $(6.882 .000,00)$ & \\
\hline Beban PPh Revaluasi & $(1.999 .769 .622,85)$ & \\
\hline Rugi Komersial & & \\
\hline
\end{tabular}

Rugi komersial kumulatif sampai dengan tanggal 31 Desember 2004 sebesar Rp.1.999.769.622,85 terdiri dari :

Rugi tahun sebelumnya yang belum dikonpensasikan :

$$
\text { Rp.6.918.716.565,85 -Rp.6.140.948.140,00 = Rp.777.768.425,85 }
$$

Rugi tahun berjalan setelah PPh Revaluasi :

$$
\text { Rp.1.215.199.197,00 + Rp.6.882.000,00 }=\underline{\text { Rp. } 1.222 .001 .197,00}
$$

Rugi Komersial Rp.1.999.769.622,85

Kebijakan penilaian kembali (Revaluasi) aset tetap yang dilakukan PDAM Tirta Jaya Mandiri Kabupaten Sukabumi mengakibatkan adanya pajak penghasilan final yang harus dibayarkan oleh perusahaan dari adanya selisih lebih akibat penilaian kembali (Revaluasi) aset tetap yang dilakukan oleh perusahaan. Berdasarkan ketentuan perpajakan, telah diatur bahwa setiap selisih lebih akibat penilaian kembali (Revaluasi) aset tetap dikenakan pajak final sebesar $10 \%$ setelah dikompensasikan ke kerugian fiskal. Sesuai dengan kebijakan penilaian kembali (Revaluasi) aset tetap yang dilakukan PDAM Tirta Jaya Mandiri Kabupaten Sukabumi terhadap aset tetapnya, maka dapat diketahui pajak final yang harus dibayarkan adalah sebesar Rp.6.882.489,22.

\subsubsection{Perubahan Kebijakan Penilaian Kembali (Revaluasi) Menjadi Model Biaya \\ Sejak tahun 2004 PDAM Tirta}

Jaya Mandiri Kabupaten Sukabumi melakukan penilaian kembali (Revaluasi) secara parsial atas aset tetap berupa tanah dan sebagian bangunan, sampai dengan tahun 2014 PDAM Tirta Jaya Mandiri Kabupaten Sukabumi belum lagi melakukan penilaian kembali (Revaluasi) aset tetapnya lagi. Perusahaan tidak lagi melakukan penilaian kembali (Revaluasi) aset tetap dikarenakan belum diterbitkannya Surat Perintah Kerja Direktur Utama PDAM Kabupaten Sukabumi yang berisikan bahwa perusahaan diharuskan melakukan penilaian kembali 
(Revaluasi) atas aset tetapnya. Selain itu, penilaian kembali (Revaluasi) aset tetap tergolong hal yang rumit dilaksanakan dan membutuhkan biaya yang cukup besar. Hal itulah yang menyebabkan PDAM Kabupaten Sukabumi tidak lagi penggunakan model revaluasi sebagai model penilaian atas aset tetapnya. Perusahaan mencatat aset tetap sebesar harga perolehan yang meliputi harga beli, biaya hukum dan broket, bea impor dan pajak pembelian yang tidak dapat dikreditkan, serta biaya-biaya yang dapat dibebankan langsung untuk membawa aset ke lokasi dan kondisi siap digunakan sesuai dengan maksud manajemen.

Sejak perubahan kebijakan penialian aset tetap, perusahaan mencatat aset tetap menggunakan biaya perolehan. Jumlah masing-masing aset tetap PDAM Kabupaten Sukabumi adalah nilai perolehan yang dikurangi dengan akumulasi penyusutan aset tetap sehingga dapatlah nilai buku dari masing-masing aset tetap tersebut. Sedangkan penyusutan aset tetap dilakukan sesuai dengan Pasal 11 Undang-Undang Nomor 36 Tahun 2008 tentang Pajak Penghasilan. Dimana berdasarkan Pasal 11 Undang-Undang Nomor 36 Tahun 2008 tentang Pajak Penghasilan, penyusutan dihitung berdasarkan kelompok aset dengan cara menerapkan tarif atas nilai sisa buku, dan pada akhir masa manfaat nilai sisa buku disusutkan sekaligus. Pada setiap tanggal pelaporan terhadap aset tetap dilakukan penilaian kemungkinan terjadi penurunan nilai aset. Penurunan nilai aset diakui sebagai beban dan dicatat dalam pos beban penurunan nilai aset.

Perkembangan aset tetap perusahaan terhitung sejak tahun 2005 sampai dengan tahun 2014 mengalami peningkatan yang cukup baik. Tidak ada penurunan dalam jumlah aset tetap bersih perusahaan. Hal tersebut dapat dilihat pada gambar 2.

PDAM Tirta Jaya Mandiri Kabupaten Sukabumi Perkembangan Aset Perusahaan Tahun 2005 - Tahun 2014

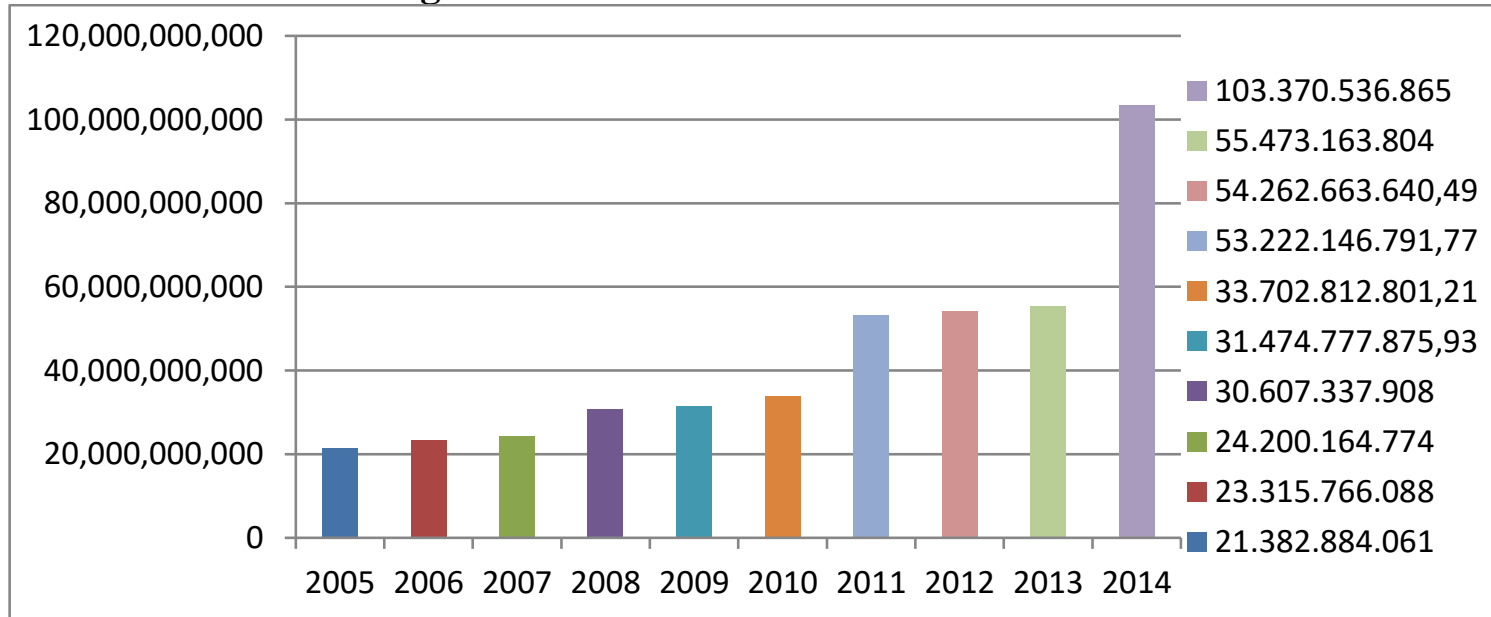

Gambar 2

Sumber data : Laporan Keuangan PDAM Tirta Jaya Mandiri Kabupaten Sukabumi Tahun 2005 - 2014 (diolah penulis)

Dari Gambar 2 di atas, terlihat jelas peningkatan aset tetap PDAM Tirta Jaya Mandiri Kabupaten Sukabumi dari tahun ke tahun semakin meningkat. Tetapi nilai-nilai 
tersebut tidak menggambarkan nilai aset tetap yang wajar berdasarkan nilai aset tetap saat ini dikarenakan perusahaan belum lagi melakukan penilaian kembali (Revaluasi) aset tetap sejak tahun 2005 dan perusahaan menggunakan harga perolehan untuk mencatat aset tetapnya. Jika ditinjau dari sisi perpajakan, penilaian kembali (Revaluasi) aset tetap dapat menghemat pajak sebesar 7\% (asumsi perusahaan mengajukan permohonan sejak 31 Oktober 2015 sampai dengan tanggal 31 Desember 2015 dan dikenakan tarif 3\%). Menghemat pajak sebesar 6\% (asumsi perusahaan mengajukan permohonan sejak 1 Januari 2016 sampai dengan tanggal 30 Juni 2016 dan dikenakan tarif $4 \%$ ) atau menghemat $4 \%$ (asumsi perusahaan mengajukan permohonan sejak 1 Juli 2016 sampai dengan tanggal 31 Desember 2016 dan dikenakan tarif 6\%). Selain itu, jika perusahaan melakukan penilaian kembali (Revaluasi) aset tetap, maka nilai aset tetap yang tercatat pada laporan keuangan perusahaan merupakan nilai aset tetap yang menggambarkan nilai sebenarnya.

Penilaian kembali (Revaluasi) aset tetap dapat dilakukan atas seluruh aset tetap yang dimiliki oleh perusahaan dengan status hak milik yang memiliki nilai yang material, dimana harga aset tersebut cukup signifikan contohnya tanah, bangunan, mesin dan kendaraan. Menurut perpajakan revaluasi aset tetap tidak dapat dilakukan kembali sebelum lewat jangka waktu 5 tahun terhitung sejak revaluasi terakhir kalinya. Sedangkan di dalam akuntansi menyebutkan bahwa frekuensi revaluasi tergantung perubahan nilai wajar dari suatu aset tetap yang direvaluasi. Jika nilai wajar dari aset yang direvaluasi berbeda secara material dari jumlah tercatatnya, maka revaluasi lanjutan perlu dilakukan. Beberapa aset tetap mengalami perubahan nilai wajar secara signifikan dan fluktuatif, sehingga perlu direvaluasi secara tahunan. Revaluasi tahunan seperti itu tidak perlu dilakukan apabila perubahan nilai wajar tidak signifikan. Namun demikian, aset tersebut mungkin perlu direvaluasi setiap tiga atau lima tahun sekali.

\subsection{Analisis Perbandingan Revaluasi Aset Tetap Sesuai PSAK No. 16 (revisi 2007) dan Dampak Perpajakannya Menurut Undang-Undang Pajak}

\subsubsection{Analisis Revaluasi Aset Tetap Sesuai PSAK No. 16 (Revisi 2007)}

Dalam PSAK No.16 (Revisi 2007) dijelaskan mengenai peraturan pelaksanaan jika perusahaan melakukan penilaian kembali (Revaluasi) aset tetap. Dalam standar ini dijelaskan bagaimana penilaian kembali (Revaluasi) aset tetap seharusnya dilakukan. Adapun analisis perbandingan penilaian kembali (Revaluasi) aset tetap yang dilakukan oleh PDAM Tirta Jaya Mandiri Kabupaten Sukabumi dapat dilihat pada tabel 11. Berdasarkan tabel 11 peneliti menganalisis dengan membandingkan Keputusan Menteri Keuangan Republik Indonesia Nomor 486/KMK.03/2002 tanggal 28 November 2002 yang dianut oleh PDAM Tirta Jaya Mandiri Kabupaten Sukabumi dengan Pernyataan Standar Akuntansi Keuangan PSAK No. 16 (Revisi 2007). Dari tabel 10 terdapat perbedaan aspek yaitu aset yang direvaluasi. Di dalam perpajakan mengizinkan revaluasi sebagian, sedangkan komersial melarang revaluasi secara selektif. Secara komersial, revaluasi harus dilakukan minimal per kelompok aset, dimana kelompok aset adalah aset yang kegunaan yang serupa, misalnya tanah, peralatan pabrik, kendaraan dan seterusnya. Misalnya terdapat 8 tanah dalam klasifikasi aset tanah dalam sebuah perusahaan, maka secara fiskal, diizinkan hanya merevaluasi 3 tanah saja, sedangkan komersial harus seluruhnya.

\section{Tabel 11}

PDAM Tirta Jaya Mandiri Kabupaten Sukabumi Penyesuaian Pelaksanaan Revaluasi Aset Tetap terhadapPSAK No.16 
(Revisi 2007)

\begin{tabular}{|c|l|l|l|}
\hline No & Aspek & $\begin{array}{c}\text { Revaluasi Aset Tetap Yang } \\
\text { Dilaksanakan PDAM Tirta Jaya } \\
\text { Mandiri Kabupaten Sukabumi } \\
\text { KMK No. 486 Tahun 2002 }\end{array}$ & PSAK No. 16 (Revisi 2007) \\
\hline 1 & Penilai & $\begin{array}{l}\text { Revaluasi aset tetap dilakukan oleh ahli } \\
\text { penilaian yang memiliki kualifikasi } \\
\text { profesional yang dinilai berdasarkan } \\
\text { nilai pasar }\end{array}$ & $\begin{array}{l}\text { Nilai wajar tanah dan } \\
\text { bangunan biasanya } \\
\text { ditentukan melalui penilaian } \\
\text { yang dilakukan oleh penilai } \\
\text { yang memiliki kulaifikasi } \\
\text { profesional berdasarkan } \\
\text { bukti pasar. } \\
\text { Paragraf 32 }\end{array}$ \\
\hline 2 & Penyusutan & $\begin{array}{l}\text { Dasar penyusutan fiskal aset tetap } \\
\text { perusahaan yang telah memperoleh } \\
\text { persetujuan penilaian kembali mulai } \\
\text { bulan dilakukannya penilaian kembali } \\
\text { adalah nilai sisa buku fiskal baru. }\end{array}$ & $\begin{array}{l}\text { Apabila suatu aset tetap } \\
\text { direvaluasi, akumulasi } \\
\text { penyusutan pada tanggal } \\
\text { revaluasi dilakukan. } \\
\text { Paragraf 35 }\end{array}$ \\
\hline 3 & $\begin{array}{l}\text { Aset yang } \\
\text { direvaluasi }\end{array}$ & $\begin{array}{l}\text { Penilaian kembali dapat meliputi } \\
\text { seluruh atau sebagian aset tetap } \\
\text { perusahaan }\end{array}$ & $\begin{array}{l}\text { Harus dilakukan atas } \\
\text { kelompok aset yang sama. } \\
\text { Paragraf 36 }\end{array}$ \\
\hline
\end{tabular}

Sumber data: Laporan Keuangan PDAM Tirta Jaya Mandiri Kabupaten Sukabumi (diolah penulis)

\subsubsection{Analisis Revaluasi Aset Tetap Sesuai PSAK No. 16 dan Undang-Undang} Perpajakan

Berbeda halnya dengan PSAK, dalam Undang-Undang Perpajakan juga dijelaskan mengenai bagaimana pelaksanaan penilaian kembali (Revaluasi) aset tetap yang dilakukan oleh wajib pajak untuk tujuan perpajakan. Analisis perbandingan penilaian kembali (Revaluasi) aset tetap yang dilakukan oleh PDAM Tirta Jaya Mandiri Kabupaten Sukabumi dapat dilihat pada tabel 12.

Tabel 12

PDAM Tirta Jaya Mandiri Kabupaten Sukabumi

Analisis Perbandingan Revaluasi Aset Tetap Sesuai PSAK No.16 dan Undang-Undang Perpajakan

\begin{tabular}{|c|l|l|l|}
\hline No & \multicolumn{1}{|c|}{ Aspek } & \multicolumn{1}{|c|}{ PMK 191/2015 } & \multicolumn{1}{|c|}{$\begin{array}{c}\text { PSAK No.16 } \\
\text { (Revisi 2007) }\end{array}$} \\
\hline 1 & $\begin{array}{l}\text { Aset yang } \\
\text { direvaluasi }\end{array}$ & $\begin{array}{l}\text { dapat dilakukan terhadap } \\
\text { sebagian atau seluruh } \\
\text { aset tetap. } \\
\text { (Pasal 3) }\end{array}$ & $\begin{array}{l}\text { Harus dilakukan atas kelompok aset } \\
\text { yang sama. } \\
\text { (Paragraf 36) }\end{array}$ \\
\hline 2 & $\begin{array}{l}\text { Frekuensi } \\
\text { revaluasi }\end{array}$ & $\begin{array}{l}\text { Dapat dilakukan kembali } \\
\text { setelah 5 tahun sejak } \\
\text { penilaian sebelumnya. } \\
\text { (pasal 3) }\end{array}$ & $\begin{array}{l}\text { Jika nilai wajar aset yang } \\
\text { direvaluasi berbeda secara material } \\
\text { dari jumlah tercatatnya, maka perlu } \\
\text { dilakukan revaluasi lanjutan. } \\
\text { (Paragraf 34) }\end{array}$ \\
\hline 3 & $\begin{array}{l}\text { Hasil penilaian } \\
\text { oleh appraisal }\end{array}$ & $\begin{array}{l}\text { Direktur Jenderal Pajak } \\
\text { dapat menetapkan }\end{array}$ & $\begin{array}{l}\text { Menggunakan pendekatan } \\
\text { pendapatan atau biaya pengganti }\end{array}$ \\
\hline
\end{tabular}




\begin{tabular}{|c|l|l|l|}
\hline & $\begin{array}{l}\text { tidak } \\
\text { mencerminkan } \\
\text { kedaan yang } \\
\text { sebenarnya }\end{array}$ & $\begin{array}{l}\text { kembali nilai pasar atas } \\
\text { aset yang bersangkutan. } \\
\text { (Pasal 4) }\end{array}$ & $\begin{array}{l}\text { yang telah disusutkan (Depreciated } \\
\text { Replacement Cost Approach) } \\
\text { (Paragraf 33) }\end{array}$ \\
\hline 4 & $\begin{array}{l}\text { Nama akun atas } \\
\text { surplus } \\
\text { revaluasi dalam } \\
\text { neraca }\end{array}$ & $\begin{array}{l}\text { Disajikan sebagai } \\
\text { "Selisih Lebih Penilaian } \\
\text { Kembali Aktiva Tetap } \\
\text { Wajib Pajak Tanggal } \\
\text { ….......... } \\
\text { (Pasal 9) }\end{array}$ & $\begin{array}{l}\text { Tidak diatur secara khusus, namun } \\
\text { secara tersirat disebutkan surplus } \\
\text { revaluasi. } \\
\text { (Paragraf 39-41) }\end{array}$ \\
\hline
\end{tabular}

Di dalam perpajakan mengizinkan revaluasi sebagian, sedangkan komersial melarang revaluasi secara selektif. Secara komersial, revaluasi harus dilakukan minimal per kelompok aset, dimana kelompok aset adalah aset yang kegunaan yang serupa, misalnya tanah, peralatan pabrik, kendaraan dan seterusnya. Misalnya terdapat 8 tanah dalam klasifikasi aset tanah dalam sebuah perusahaan, maka secara fiskal, diizinkan hanya merevaluasi 3 tanah saja, sedangkan komersial harus seluruhnya. Di dalam komersial aset-aset dalam suatu kelompok aset tetap harus direvaluasi secara bersamaan untuk menghindari revaluasi aset tetap secara selektif dan bercampurnya biaya perolehan dan nilai lainnya pada saat yang berbeda. Di dalam perpajakan revaluasi aset tetap dapat dilakukan kembali setelah 5 tahun sejak penilaian kembali sebelumnya. Sedangkan di dalam akuntansi frekuensi revaluasi aset tetap tergantung pada perubahan nilai wajar dari aset tetap yang direvaluasi dan dapat dilakukan setiap 1 tahun sekali.

Di dalam perpajakan jika hasil penilaian oleh jasa penilai tidak mencerminkan keadaan yang sebenarnya, wewenang yang berhak menetapkan kembali nilia pasar atas aset yang direvaluasi adalah Direktur Jenderal Pajak. Sedangkan di dalam akuntansi terdapat pendekatan yang dapat digunakan untuk menilai aset tetap jika tidak ada data pasar yang dapat dijadikan dasar penentuan nilai wajar dari aset tetap yang direvaluasi.

Perbedaan terakhir pada aspek nama akun atas surplus revaluasi dalam neraca, menurut perpajakan telah jelas nama akun atas surplus tersebut, sedangkan dalam akuntansi tidak dijelaskan mengenai nama akun tersebut.

\subsubsection{Analisis Penyesuaian Pelaksanaan Revaluasi Aset Tetap}

Dalam penelitian ini penulis telah merekap pelaksanaan penilaian kembali (revaluasi) aset tetap yang dilakukan oleh PDAM Tirta Jaya Mandiri Kabupaten Sukabumi dan disesuaikan dengan PMK No 191/PMK.010/2015 yang disajikan pada tabel 13.

Tabel 13

PDAM Tirta Jaya Mandiri Kabupaten Sukabumi Penyesuaian Pelaksanaan Revaluasi Aset Tetap Menurut Undang-Undang Perpajakan

\begin{tabular}{|c|c|c|}
\hline No & $\begin{array}{c}\text { Undang-Undang yang Dianut PDAM } \\
\text { Tirta Jaya Mandiri Kabupaten } \\
\text { Sukabumi Dalam Melaksanakan } \\
\text { Revaluasi Aset Tetap }\end{array}$ & $\begin{array}{c}\text { Undang-Undang Perpajakan yang } \\
\text { Berlaku Saat Ini }\end{array}$ \\
\hline 1 & $\begin{array}{l}\text { Penilaian kembali aset tetap perusahan } \\
\text { harus dilakukan berdasarkan nilai pasar } \\
\text { atau nilai wajar aset tetap tersebut yang } \\
\text { berlaku pada saat penilaian kembali yang }\end{array}$ & Pasal 1 Ayat 3 \\
\hline
\end{tabular}




\begin{tabular}{|c|c|c|}
\hline & $\begin{array}{l}\text { ditetapkan oleh perusahaan jasa penilai } \\
\text { atau ahli penilai yang diakui atau } \\
\text { memperoleh izin Pemerintah. }\end{array}$ & \\
\hline 2 & $\begin{array}{l}\text { Aset tetap perusahaan sebagaimana } \\
\text { dimaksud dalam Pasal } 1 \text { adalah aktiva } \\
\text { tetap berwujud yang terletak atau berada } \\
\text { di Indonesia, yang dimiliki dan } \\
\text { dipergunakan untuk mendapatkan, } \\
\text { menagih, dan memelihara penghasilan } \\
\text { yang merupakan Objek Pajak. }\end{array}$ & Pasal 3 Ayat 1 \\
\hline 3 & Ketentuan penyusutan fiskal aset tetap & Pasal 7 Ayat 2 \\
\hline 4 & $\begin{array}{l}\text { Atas selisih lebih penilaian kembali di } \\
\text { atas nilai sisa buku fiskal semula setelah } \\
\text { dikompensasikan terlebih dahulu dengan } \\
\text { sisa kerugian fiskal tahun-tahun } \\
\text { sebelumnya berdasarkan ketentuan Pasal } \\
6 \text { ayat (2) Undang-undang Pajak } \\
\text { Penghasilan yang berlaku, dikenakan } \\
\text { Pajak Penghasilan yang bersifat final } \\
\text { sebesar } 10 \% \text { (sepuluh persen). }\end{array}$ & $\begin{array}{l}\text { Perlakuan khusus sebagaimana } \\
\text { dimaksud pada ayat (1) berupa Pajak } \\
\text { Penghasilan yang bersifat final } \\
\text { sebesar: } \\
\text { 3\% (tiga persen), untuk permohonan } \\
\text { yang diajukan sejak berlakunya } \\
\text { Peraturan Menteri ini sampai dengan } \\
\text { tanggal 31 Desember } 2015 \\
\text { 4\% (empat persen), untuk } \\
\text { permohonan yang diajukan sejak } 1 \\
\text { Januari 2016 sampai dengan tanggal } \\
\text { 30 Juni 2016; atau } \\
\text { 6\% (enam persen), untuk } \\
\text { permohonan yang diajukan sejak } 1 \\
\text { Juli 2016 sampai dengan tanggal } 31 \\
\text { Desember 2016. } \\
\text { (Pasal 1) }\end{array}$ \\
\hline
\end{tabular}

Sumber data : Laporan Keuangan PDAM Tirta Jaya Mandiri Kabupaten Sukabumi (diolah penulis)

Pada tabel 13 terdapat perbedaan yang cukup menarik dimana perbedaan tersebut terjadi pada tarif pajak penghasilan yang bersifat final. Pada tahun 2015 pemerintah menetapkan diskon tarif jika perusahaan melakukan revaluasi aset tetapnya pada masa yang telah ditetapkan oleh pemerintah.

\subsubsection{Analisis Dampak Penilaian Kembali (Revaluasi) Aset Tetap}

Seperti yang dapat kita ketahui, penilaian kembali (Revaluasi) aset tetap mempunyai dampak bagi perusahaan. Tanah merupakan jenis aset tetap yang tidak dapat disusutkan, sehingga penilaian kembali (Revaluasi) aset tetap yang dilakukan pada aset tetap tanah tidak akan memberikan kontribusi pada penghematan pajak bagi perusahaan karena tidak menghasilkan beban penyusutan. Padahal aset tetap berupa tanah memiliki nilai penilaian kembali (Revaluasi) yang cukup besar dan tentu akan menghasilkan pajak final atas selisih lebih penilaian kembali (Revaluasi). Selisih lebih tersebut dapat dikompensasikan ke kerugian fiskal bila perusahaan memiliki kerugian fiskal yang belum dikompensasikan. Aset tetap perusahaan berupa bangunan dan peralatan merupakan aset tetap yang dapat disusutkan, sehingga hasil revaluasi terhadap bangunan dan peralatan mampu memberikan kontribusi penghematan pajak melalui 
peningkatan beban penyusutan akibat bertambahnya nilai buku dari kedua aset tetap tersebut.

Adanya penilaian kembali aset tetap (Revaluasi) membantu Pemerintah atau badan Direktorat Jenderal Pajak untuk meningkatkan penerimaan negara yang diperoleh dari Pajak Penghasilan Badan. Adanya revaluasi juga membantu wajib pajak atau pemilik perusahaan untuk membuat perencanaan perpajakan yang bertujuan untuk menghemat pembayaran pajak. Dengan adanya penilaian aset tetap akan memberikan dampak bagi perusahaan:

1. Posisi kekayaan di dalam neraca menunjukkan kewajaran, ini akan mempermudah pemakai laporan keuangan untuk mendapatkan informasi yang tepat dan akurat.

2. Selisih lebih penilaian kembali akan menyebabkan struktur modal meningkat.

3. Naiknya nilai aset tetap menyebabkan beban penyusutan aset tetap menjadi naik yang di bebankan dala laba/ rugi.

4. Dari segi perpajakan bahwa selisih lebih yang disebabkan revaluasi aset tetap adalah objek pajak yang dikenai pajak penghasilan final 10\%. Menurut PMK $191 / 2015$, penilaian kembali (Revaluasi) aset tetap dapat menghemat pajak sebesar 7\% (asumsi perusahaan mengajukan permohonan sejak 31 Oktober 2015 sampai dengan 31 Desember 2015 dan dikenakan tarif 3\%). Menghemat pajak sebesar 6\% (asumsi perusahaan mengajukan permohonan sejak 1 Januari 2016 sampai dengan tanggal 30 Juni 2016 dan dikenakan tarif 4\%) atau menghemat 4\% (asumsi perusahaan mengajukan permohonan sejak 1 Juli 2016 sampai dengan tanggal 31 Desember 2016 dan dikenakan tarif 6\%).

\subsection{Evaluasi Terhadap Analisis Perbandingan Atas Model Revaluasi Aset Tetap Sesuai PSAK No.16 (Revisi 2007) dan Dampak Perpajakannya Menurut Undang-Undang Pajak Pada PDAM Tirta Jaya Mandiri Kabupaten Sukabumi Periode 2014}

Ada tiga tujuan penelitian skripsi ini, tujuan penelitian yang pertama yaitu "Untuk mengetahui kecukupan atas keteraturan melakukan revaluasi aset tetap sesuai ketentuan Pernyataan Standar Akuntansi Keuangan (PSAK) No.16 (Revisi 2007) PDAM Tirta Jaya Mandiri Kabupaten Sukabumi”. Setelah penulis analisa mengenai pelaksanaan penilaian kembali (Revaluasi) aset tetap yang dilakukan oleh PDAM Tirta Jaya Mandiri Kabupaten Sukabumi, bahwa kecukupan atas keteraturan melakukan revaluasi aset tetap sesuai PSAK No. 16 (Revisi 2007) belum terpenuhi. Di dalam perpajakan mengizinkan revaluasi sebagian, sedangkan komersial melarang revaluasi secara selektif. Secara komersial, revaluasi harus dilakukan minimal per kelompok aset, dimana kelompok aset adalah aset yang kegunaan yang serupa, misalnya tanah, peralatan pabrik, kendaraan dan seterusnya. Misalnya terdapat 8 tanah dalam klasifikasi aset tanah dalam sebuah perusahaan, maka secara fiskal, diizinkan hanya merevaluasi 3 tanah saja, sedangkan komersial harus seluruhnya.

Tujuan penelitian yang kedua "Untuk mengetahui apakah perusahaan perlu melakukan revaluasi atas aset tetap yang belum dilakukan revaluasi pada periode sebelumnya PDAM Tirta Jaya Mandiri Kabupaten Sukabumi”. Penulis menganalisa frekuensi revaluasi tergantung perubahan nilai wajar dari suatu aset tetap yang direvaluasi. Jika nilai wajar dari aset yang direvaluasi berbeda secara material dari jumlah tercatatnya, maka revaluasi lanjutan perlu dilakukan. Beberapa aset tetap mengalami perubahan nilai wajar secara signifikan dan fluktuatif, sehingga perlu direvaluasi secara tahunan. Revaluasi tahunan seperti itu tidak perlu dilakukan apabila 
perubahan nilai wajar tidak signifikan. Namun demikian, aset tersebut mungkin perlu direvaluasi setiap tiga atau lima tahun sekali. Tidak ada keharusan untuk perusahaan melakukan atau tidak melakukan revaluasi atas aset tetap yang belum direvaluasi, karena melakukan atau tidaknya merupakan kebijakan internal perusahaan. Aturan perpajakan hanya memfasilitasi jika perusahaan ingin melakukan revaluasi atas aset tetapnya.

Tujuan penelitian yang ketiga "Untuk mengetahui bagaimana dampak revaluasi aset tetap terhadap perpajakan PDAM Tirta Jaya Mandiri Kabupaten Sukabumi”. Setelah penulis menganalisa dampak yang ditimbulkan jika perusahaan melakukan revaluasi akan menghasilkan pajak penghasilan final atas selisih lebih penilaian kembali (Revaluasi). Selisih lebih tersebut dapat dikompensasikan ke kerugian fiskal bila perusahaan memiliki kerugian fiskal yang belum dikompensasikan. Jika ditinjau dari sisi perpajakan, penilaian kembali (Revaluasi) aset tetap dapat menghemat pajak sebesar 7\% (asumsi perusahaan mengajukan permohonan sejak 31 Oktober 2015 sampai dengan 31 Desember 2015 dan dikenakan tarif 3\%). Menghemat pajak 6\% (asumsi perusahaan mengajukan permohonan sejak 1 Januari 2016 sampai dengan tanggal 30 Juni 2016 dan dikenakan tarif $4 \%$ ) atau menghemat $4 \%$ (asumsi perusahaan mengajukan permohonan sejak 1 Juli 2016 sampai dengan tanggal 31 Desember 2016 dan dikenakan tarif 6\%). Diskon tarif yang diberlakukan pada tahun 2015 sebenarnya peluang bagi perusahaan yang baik untuk dimanfaatkan oleh perusahaan. Pemberian insentif perpajakan ini dimaksudkan sebagai pendorong wajib pajak agar semakin taat terhadap ketentuan peraturan perpajakan. Jika wajib pajak memanfaatkan kesempatan ini itu berarti wajib pajak memberikan dukungan positif dalam pencapaian target penerimaan negara dari pajak. Dalam praktiknya PDAM Tirta Jaya Mandiri Kabupaten Sukabumi tidak memanfaatkan adanya diskon tarif yang disediakan oleh pemerintah.

\section{Penutup}

\subsection{Simpulan}

Kesimpulan yang diperoleh penulis dari hasil penelitian dan pembahasan Perbandingan Model Revaluasi Aset Tetap Pada PDAM Tirta Jaya Mandiri Kabupaten Sukabumi Periode 2014 adalah sebagai berikut :

1. Kecukupan atas keteraturan melakukan revaluasi aset tetap yang dilakukan oleh PDAM Tirta Jaya Mandiri Kabupaten Sukabumi belum terpenuhi dan belum sesuai dengan PSAK No. 16 (Revisi 2007).

2. Frekuensi revaluasi tergantung perubahan nilai wajar dari suatu aset tetap yang direvaluasi. Jika nilai wajar dari aset yang direvaluasi berbeda secara material dari jumlah tercatatnya, maka revaluasi lanjutan perlu dilakukan. Beberapa aset tetap mengalami perubahan nilai wajar secara signifikan dan fluktuatif, sehingga perlu direvaluasi secara tahunan. Revaluasi tahunan seperti itu tidak perlu dilakukan apabila perubahan nilai wajar tidak signifikan. Namun demikian, aset tersebut mungkin perlu direvaluasi setiap tiga atau lima tahun sekali. Tidak ada keharusan untuk perusahaan melakukan atau tidak melakukan revaluasi atas aset tetap yang belum direvaluasi, karena melakukan atau tidaknya merupakan kebijakan internal perusahaan. Aturan perpajakan hanya memfasilitasi jika perusahaan ingin melakukan revaluasi atas aset tetapnya.

3. Dampak yang ditimbulkan jika perusahaan melakukan revaluasi akan menghasilkan pajak penghasilan final atas selisih lebih penilaian kembali (Revaluasi). Selisih lebih tersebut dapat dikompensasikan ke kerugian fiskal bila 
perusahaan memiliki kerugian fiskal yang belum dikompensasikan. Jika ditinjau dari sisi perpajakan, penilaian kembali (Revaluasi) aset tetap dapat menghemat pajak sebesar 7\% (asumsi perusahaan mengajukan permohonan sejak 31 Oktober 2015 sampai dengan 31 Desember 2015 dan dikenakan tarif 3\%). Menghemat pajak 6\% (asumsi perusahaan mengajukan permohonan sejak 1 Januari 2016 sampai dengan tanggal 30 Juni 2016 dan dikenakan tarif 4\%) atau menghemat 4\% (asumsi perusahaan mengajukan permohonan sejak 1 Juli 2016 sampai dengan tanggal 31 Desember 2016 dan dikenakan tarif 6\%). Diskon tarif yang diberlakukan pada tahun 2015 sebenarnya peluang bagi perusahaan yang baik untuk dimanfaatkan oleh perusahaan. Pemberian insentif perpajakan ini dimaksudkan sebagai pendorong wajib pajak agar semakin taat terhadap ketentuan peraturan perpajakan. Jika wajib pajak memanfaatkan kesempatan ini itu berarti wajib pajak memberikan dukungan positif dalam pencapaian target penerimaan negara dari pajak. Dalam praktiknya PDAM Tirta Jaya Mandiri Kabupaten Sukabumi tidak memanfaatkan adanya diskon tarif yang disediakan oleh pemerintah.

\subsection{Saran}

Dalam penelitian ini penulis berharap dapat memberikan kontribusi dalam pengembangan ilmu pengetahuan di bidang ekonomi akuntansi khususnya akuntansi perpajakan. Berikut ini adalah saran penulis bagi perusahaan yaitu :

1. Perusahaan dapat melakukan pembenahan ulang dalam pencatatan biaya yang terkait dengan aset tetap agar sesuai dengan standar yang berlaku.

2. Perusahaan seharusnya lebih teliti dalam mengelompokan biaya yang dapat dikapitalisasi ke dalam aset tetap dan biaya yang tidak dapat dikapitalisasi ke dalam aset tetap.

3. Pengeluaran-pengeluaran setelah perolehan aset tetap yang bersifat menambah manfaat umur aset, dapat dibebankan langsung terhadap pengeluaran modal, dalam hal ini perusahaan harus lebih menekankan apakah kebijakan yang di ambil dalam pengeluaran yang terjadi selama masa manfaat penggunaan aset tetap tersebut. Apakah pengeluaran modal atau pengeluaran pendapatan, yang dapat digolongkan sesuai dengan besarnya pengeluaran tersebut.

4. Sebaiknya perusahaan melakukan revaluasi aset tetapnya dengan mempertimbangkan dampak-dampak yang ditimbulkan dari kegiatan tersebut bagi perusahaan.

\section{Daftar Pustaka}

Erly Suandy. 2013. Perencanaan Pajak. Jakarta: Salemba Empat.

IAI. 2007. PSAK No 16 Aset Tetap. Jakarta: Dewan Standar Akuntansi Keuangan. Undang-Undang Republik Indonesia Nomor 36 Tahun 2008 tentang Perubahan

Keempat atas Undang-Undang Nomor 7 Tahun 1983 tentang Pajak Penghasilan

Wirawan dan Diaz Priantara. 2015. Perpajakan. Jakarta: Mitra Wacana Media. 